\title{
Erratum to: The nasopharyngeal microbiota of beef cattle before and after transport to a feedlot
}

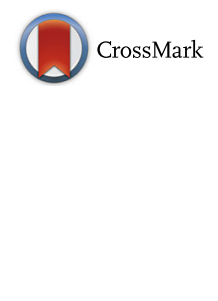

Devin B. Holman ${ }^{1}$, Edouard Timsit ${ }^{2}$, Samat Amat ${ }^{3}$, D. Wade Abbott ${ }^{3}$, Andre G. Buret ${ }^{4}$ and Trevor W. Alexander ${ }^{3^{*}}$

\section{Erratum}

Upon publication of the original article [1] it was noted that our Standard Copyright was incorrectly attributed to this manuscript. The correct copyright attributed to this paper is as follows:

“@ Her Majesty the Queen in Right of Canada 2017. This article is distributed under the terms of the Creative Commons 4.0 Attribution License (http://creativecommons.org/ licenses/by/4.0/), which permits unrestricted use, distribution, and reproduction in any medium, provided you give appropriate credit to the original author(s) and the source, provide a link to the Creative Commons license, and indicate if changes were made. The Creative Commons Public Domain Dedication waiver (http://creativecommons.org/ publicdomain/zero/1.0/) applies to the data made available in this article, unless otherwise stated."

This has now also been corrected in the original article.

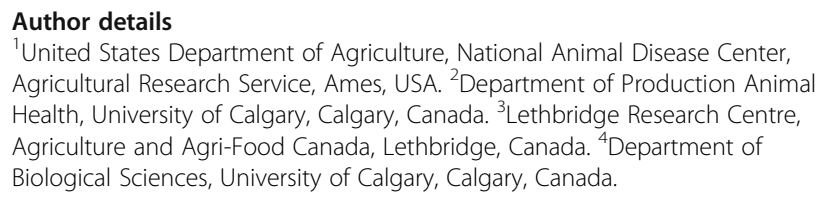

Received: 11 April 2017 Accepted: 11 April 2017

Published online: 20 April 2017

\section{Reference}

1. Holman DB, Timsit E, Amat S, Abbott DW, Buret AG, Alexander TW. The nasopharyngeal microbiota of beef cattle before and after transport to a feedlot. BMC Microbiol. 2017;17(1):70.

\footnotetext{
*Correspondence: trevor.alexander@agr.gc.ca

${ }^{3}$ Lethbridge Research Centre, Agriculture and Agri-Food Canada, Lethbridge, Canada

Full list of author information is available at the end of the article
} 